\title{
IMPACT OF SCIENCE AND SCIENTIFIC WORLDVIEW ON MAN: A CRITICAL REVIEW
}

\author{
Okechukwu Maurice Izunwa \\ doi: http://dx.doi.org/10.4314/og.v8i1.9
}

\begin{abstract}
As it relates to man, the conscious subject of scientific exploits, science could be a positive and/or a negative device in the course of nature. In so far as it rises to the occasion of the imperative of stewardship "till the earth", it remains a good news to man. But when and where it reflects the Cartesian inspiration of turning men into "lords and possessors of nature" it constitutes a lethal tool against humanity. Consequently, at the various levels of the physical, intellectual and metaphysical realms, it is not difficult to isolate a plethora of positive constitutions of science as well as an enormity of its disservice to humanity. Indeed, no genuine history and/or records of the world's progress and civilization can ignore the details and protocols of the scientific method without becoming disreputable. And none can "sanctify" all of science's interventions without turning into a heresy of history. Science had volunteered great bangs in electricity, automobile and computer engineering, informatics and architecture, aeronautic and naval engineering to mention a few. It has provided sundry remedy to diseases through medical researches. Yet it has also bequetted to humanity an ensemble of violence and war, a culture of death and a godless world of unbelief. This essay sings the redemption song of science and men of science, it praises the dominion of science but cautious against a looming sumersualt into a fettered world of violence and death. What it recommends is for the education and repositioning of science back its proper and pristine complementary paradigm of reality. In all, it makes a case for re-rooting science into its Christian origins where the laws of science are but a natural revelation of the "mystery" behind the universe, where the inspiration is "to till the earth" than "to subdue it" and where the ethical perspective of science are prior to the marvel's of its "actions".
\end{abstract}




\section{Introduction}

We find an interesting point of departure in the Christian Scripture precisely the book of Genesis which recorded an account of the creation of the world. Having created man, according to this report, God said:

Let us make man in our own image, in the likeness of ourselves and let them be masters of the fish of the sea, the birds of heaven, the cattle, all the wild animals and all the creatures that creep along the ground. God blessed them saying to them, "be fruitful, multiply, fill the earth and subdue it. Be masters of the fish of the sea, the birds of heaven and all the living creatures that move on the earth". God also said "Look, to you I give all the seedbearing plants everywhere on the surface of the earth, and all the tree with seed-bearing fruit; this will be your food."1

In this rather long sacred passage usually regarded by biblical scholars as the great imperative or the Genesis imperative, man received the impetus to exert dominion over Nature. Consequently, as co-creators with God, albeit in a secondary capacity, he has to impose form, structure, order and regularity on the amorphous substrate of matter and in this way, move nature from chaos to $\operatorname{cosmos}^{2}$ and therefore towards an increasing availability for usefulness.

Notice thus that from the earliest times in the most ancient cities of mankind, man did begin to explore this possibility of dominion procured for the betterment of his sundry affairs, an exercise that was to culminate in the scientific explosion of the $17^{\text {th }}$ and $18^{\text {th }}$ centuries, and would make great studies in the $19^{\text {th }}$ and $20^{\text {th }}$ centuries. Any good evaluation of the progress of man's scientific engagement will reveal that this man unspecialized by nature ${ }^{3}$ as he is has continued nevertheless to assert himself in different cosmological contexts most of which posed to be inimical to his survival. In all these, he advanced and adjusted by the leaps and bounds with the help of his inventive scientific genius. Now, after 
the question of survival of man, came that of conquering the world (libido dominandi) ${ }^{4}$ Here, it is no longer to survive in the midst of alien nature; it is to subject nature to the free instructions of man. Yet today, the issue has progressively come to that of absolutizing science and, therefore man, at a great disadvantage though. In basic outlines, therefore, the impact of science on man has moved in three stages: Physical; Intellectual \{Epistemological\}and Metaphysical.

These scientific tempers, so outlined had been contemplated and given form in the constructs of the founding fathers of scientific knowledge. Hence, for Francis Bacon, man has to emerge as "servants and interpreters of nature" because "science is power." Science, here, means empirical science. Rene Descartes, popularly called the great father of the Enlightenment worldview, which is basically scientific, announced that men must stand out as lords and possessors of nature.

In the first part of this paper, we intend to look constructively at the concepts of science and technology, the nature of man who does scientific exploits and who is also the beneficiary as well as the victim of scientific progress and excesses respectively. The first section of the second part will contemplate with historical bias the positive impacts of science and scientific worldview on man while the second section of the second part will engage the grossly negative impact of science and scientific knowledge on man. Finally, an attempt will be made to evaluate the impacts by way of suggesting avenues for improved appropriation of the benefits of scientific progress and also proposing workable remedies to the destructive excesses of modern science.

\section{Operative Concepts: \\ Science}

Generally, the word science coming from Latin (scientia) means knowledge. It signifies a whole body of ideas referring to the same object (or realm of objects) which are logically connected and interconnected. Asked to outline the essential characteristics of science, we indicate the logic of scientific fallibilism, conveniently expounded in terms of: Systematic coherence; logical connectivity; openness to inquiry of methods and results; methodological progression and thinking; and use of scientific terminology. 
However, science, as we have described above, appertains broadly to all forms of organized or demonstrative knowledge including the speculative or theoretical and natural sciences. Yet, when reference is specifically made to the material sciences of physics and chemistry or biology, the designation is usually physical science or empirical science. And, as a matter of fact, the emphasis of this paper sways more to the physical sciences. What then is physical science all about? The adjective 'physical' is etymologically derived from the Greek "Physics" meaning nature. In the context of its use in science, "it is understood in contrast to everything mental as that which is purely material and pertains only to sense experience." Physical science focuses and engages the totality of value, trying to understand it scientifically. Physics, chemistry, biology, etc., attempt "to analyze all natural phenomena by means of induction which relies on observation and experiment; it also attempts to discover the laws operative in nature (natural law) and so to establish an orderly system (scientific view of the world) that offers an intelligible explanation of nature."7 What clearly distinguishes the exact physical sciences from sciences in general is their capacity to express their results in mathematical formulae and thereby attain significant precision leading to specialized competence and perfection. Notice that the division of physical science into its various branches of physics, chemistry, astronomy etc. is determined by the different aspects of nature they study, and also lean somewhat to the necessity for specialisation.

\section{Technology}

Technology as a concept has been used in Greek "tecne" and "ars" respectively meaning "technique" and "arts" in that order understood in the ancient world and in the middle ages. Traditionally, it denotes the shaping of sensible perceptible things in the service of some need or idea. In this way, it includes the ability to provide both the necessary (manufacture of things) and the beautiful (giving visibility to an idea). Precisely as opposed to arts, technology is the exploitation of nature in order to satisfy man's needs. Do observe that the success of this exploitation is necessarily dependent on some basic scientific knowledge. 
Ancient technology (manual technology) was limited to the use of hand tools without much increase of work power and later to the so called work-machines like pulleys and wedge which provided increase in work power. Modern technology popularly called machines technology has advanced to the use of power tools and machines e.g. steam engines and electric motors. In the context of the above, technology can be defined as:

The methodical utilization of natural resources and forces on the bases of the knowledge of nature in order to take care of man's needs. ${ }^{8}$

Thus, technology is a necessary correlative of science and it concerns the practical utilization of the theoretical aspect of scientific knowledge. Simply put, it is science with "unsatisfactory" bias. Hence, to talk of science is almost always followed by talks on technology leading to a contemporary denigration of "pure science" which cannot be directly used in technology.

\section{Scientific Worldview}

By scientific worldview (Weltanschauung) is meant the fixed mode of appreciation, understanding and action proper to the scientific mind. It refers to the logical geography of the physical sciences, that is, the categories of understanding and vision of reality with which the scientific man confronts nature. It is a complex of the biases, prejudices and presuppositions of the basically scientific mind. This will include the penchant for: Method; logic of causes and effect (empirical causality); systematization; pften prejudicial to transcendence; and material reductionism as a hermeneutical option, etc.

\section{Man: Beneficiary and Victim of Scientific Progress}

Man is a problem and a perennial problem. Little wonder the Fathers of the Second Vatican Council were minded to ask again; what is man? The Council observed that in all attempts to answer this question man either absolutises himself or "debases himself to the point of despair." It is therefore, important to understand the nature of man in other to profitably adjudge on him the impact of any 
scientific venture on him. For the work of science is to build and consolidate man for what he is and not to destroy, deny or attempt to change him into what he is not.

Classical philosophy teaches that man is a unity of body and soul with "reason" and "will" as the two powers of his soul. Any scientific or technological prowess or feat that is prejudicial to this traditional and classical composite is arguably vitiated. Hence while supporting the body in its entire physical ramification, and while responding to all material indices of the human person, science, to be healthy, must perceive itself as complementary perspective to a holistic view of reality and so make proper provision for integral humanism, in which sufficient allowance is given to the free enterprise and dignity of man in his spiritual essence.

As a matter of fact, "man is not deceived when he regards himself as superior to bodily things (subject matter of the sciences)... when he recognizes in himself a spiritual and immortal soul, he is not being led astray by false imaginings that are due to merely physical or social causes. On the contrary, he grasps what is profoundly true in this matter." 10 While it is recognized that the instrument of science cannot reach this numinous spiritual essence in man to verify or enhance it with experiments or technological remedies, it is sufficient that all scientific advances and inquiries presuppose this other side of the human nature. Any exclusion of this "spiritual other side" will collapse science into scientism - a gross reductionism indeed unto a great disadvantage of the scientific progress and the overall integrity of the human subject. Notice that the above is a tight conclusion of reason, for man had always affirmed that by his intellect he supposes the world of mere things. Through the ages, he had progressed in the empirical sciences, in technology and in liberal arts. What is more? He had successfully inquired into the material universe and brought it under control. Yet "he has always looked for and found truth of a higher order. For his intellect is not confined to the range of what can be observed by the senses. It can with genuine certainty reach to realities known only to the mind."11

Even etymological consideration provides a balanced picture of the nature of man. Man comes from the Anglo-Saxon word "Mann", which is closely related to the Latin "mens" meaning "a thinking 
being". Also, a useful construction of the Greek "anthropos" as "one who looks upwards" has been found. Reading these in conjunction with the Latin "homo" meaning "one born of the earth," therefore, we may logically design that, on the one hand, man is "a creature of the earth like all earthly things, on the other hand, he rises above the earth and strives for a higher world." 12 In basic outlines, therefore, man in his being and action is living in a number of horizons: (1) He is a corporeal being composed of the material stuff of the inorganic world; (2) He is a living body or organism uniting in himself all the appearances and activities of bodily life which he has in common with plants and animals; and (3) He possesses spiritual and intellectual life which are intrinsically independent of everything material.

Any attempt to explain him by (1) alone will lapse into anthropological materialism; if by (2) a case of biological materialism will arise; and if by (3) spiritualism of a dangerous type will indicate. The truth is that "he exists as a unified whole in spite of his complexity. This unity is particularly furthered by the fact that the spiritual soul is also the principle of the existence of man's vegetative and sensible activities and together with the body forms one existent."13 What this means is that though of a spiritual essence, "it is in the material world of time and space that man must work for moral maturity. And in this enterprise, man's spiritual nature gradually reveals itself in the creative shaping and transformation of historical culture."14

It is overly important to advance the thesis that the human person is a reality which by itself is an end, and who therefore, must in the same token be treated with a dignity corresponding to that estimate of his status. Hence, the human person, precisely because he cannot be used as a means, is not determined for any "purpose' 15 other than himself as the very end of all nature gifts. The scandal of contemporary science and technology makes nonsense of this truth and continuously treats man as a thing, a means, one amongst the mere objects of nature. Yet "man is essentially nothing at all, but a value, res sacra homo, an ultimate end like God in whose image he is made." 16 Lewis had in his plethora of words insisted that persons "are ultimate ends and ought never to be treated only as means; they always have the character of "thou" and ought never to be treated 
merely as "it." 17 Without this, men would inevitably turn first into homosciens and then into nature.

For man to survive and thus continue to carry on scientific inquiries, science and technology must recognise the other side of man - the spiritual. Without this, man cannot remain man and without man the sciences will be no more. The reason is for what Huxley pointed out in his Ends and Means, saying that "it is impossible to live without a metaphysics. The choice that is given is not between some kind of metaphysics and no metaphysics. It is always between good metaphysics and a bad metaphysics." 18 The point is that "man embodies and reveals something unique that draws us into the realm of value and meaning, a realm qualitatively distinct from and logically prior to scientific procedures and terms, a realm from which they derive whatever rational coherence, validity and application they have."19

Every authentic scientific ideology or achievement should also consider the fact that man is a historical being, a free moral agent, a cultural, socio-economic and itinerant creature. Such scientific ventures ought to be minded at improving man in these potentialities of his nature, and never to vitiate any of them. ${ }^{20}$ Any attempt to derogate from a holistic, and essentially transcendent vision of man will outwork great ills. This is because the "scientistic" style is always to reduce things to mere nature and conquer them. If care is not taken, the logical consequence of this "scientistic" tendency will be for science to take the fatal step of reducing "our species to the level of mere nature and conquer it." 21

\section{Impact Analysis}

Our preferred method will be to look at the practical impacts or otherwise material impacts of the scientific ideology. Under this we shall consider such sub-heads as (1) stage of survival (ii) stage of dispassionate combatant inquiry and dominion over nature (iii) the stage of absolutizing science. Thereafter, this discourse progresses to consider the intellectual and mental impacts. At this point, the epistemological implications of the scientific worldview will be engaged. And finally, the religio-spiritual impact will be x-rayed. It is noticeable that our paradigm is designed tendentiously to reflect the classical composite nature of man; this model hardly needs any 
defense, for even if a meta-empirical determination of the composite principles of man is set-aside for the sake of argument, the reality of man's conscious experiences surely overwhelms any partial or sole material explanation. The experiential features of human knowledge and consciousness, sui generis warrants multi-variant frame of explanation.

\section{Practical Impacts (Physical) Stage of Survival}

It is indubitable that when science impinges on people's lives, it does so often at the practical plane presto technology. Impacts on the intellectual horizons are less frequent, indeed, uncommon, as only few people understand scientific principles. From the time man found himself in the world's stage, it appears as if the elements of nature went into grave conspiracy against him. Hence the first task facing man was to survive amidst the aggressive nature apparently populated with capricious divinities. Then, to conciliate the forces of nature man turned to myths and religious rites. Here nature is considered to be semi-divine having her own secrets which the gods possess exclusively. In this context, any attempt to exploit nature by scientific genius, will be tantamount to irreverence. If for instance "disaster results from attempts to apply man's scientific knowledge, it is his punishment for prying into the sacred mysteries of gods.",2 The general belief then is that it is only through magical formulae that men could gain access into nature's pathways.

However, magic failed to build houses and voodoo failed to feed the ancient men. At the instance of this reality, they began to exploit nature with rudimentary technology and science. Thus, "it was vital to develop faculties of observation and experimentation, people had to recognize which plants were useful and which were harmful. It was advantageous to observe the habits of animals in order to hunt them better. It was also important to select those stones which might serve as tools or from which metals could be extracted." 23 Our forbears did just these and it delivered because they survived.

In Egypt, particularly, geometry was invented in the course of aggressive search for the solutions to the concrete problems of

surveying and parceling out land. Alongside the Egyptian 
civilization, Mesopotamia was also a brilliant centre for originating subsistent scientific culture. "As a matter of fact, the world owes to the Sumerians the invention of writing which spread as far as China." 24

\section{Stage of Dispassionate and Combatant Spirit to Conquer the World}

Paul Davies in his God and the New Physics exclaimed:

There is no doubt, however about the success of the scientific method. Physics, the Queen of sciences has opened up vistas of human understanding that were unsuspected a few centuries ago. From the inner workings of the atoms to the weird surrealism of the blackhole, physics has enabled us to comprehend some of nature's darkest secrets and to gain control over many physical systems on our environment. The tremendous power of scientific reasoning is demonstrated daily in many marvels of modern technology. It seems reasonable then to have some confidence in the scientist's worldview. ${ }^{25}$

At this level, science has really taken off at a very vulnerable speed. The Renaissance was the launching ground for that great agenda that was in future to emasculate the world, so to speak. Men first began to do exploit into unraveling the laws and fundamental principles of nature to quite great advantages. Such laws as: ${ }^{26}$

(i) Newton's law of gravitational attraction was important in understanding how the celestial bodies hold together without sundering and how 'bodies' on earth hold similar attractions without collapsing against each other.

(ii) Appreciation of Newton's three (3) laws of motion was significant in the rocket technology, manufacture of guns with effective shooting and the development of projectiles. 
(iii) Newton's systematization of the principle of 'movement of a force' (which states that 'movement of a force about a point is the product of the force and the perpendicular distance of its line of action from the point) was essential for development of carriage cranes and more importantly, designing cars with stability after taking into consideration the centre of gravity.

(iv) The law of conservation of energy when discovered was useful for storage of energy with sensitive devices and converting some to contingent necessities i.e. to required forms.

(v) One of the most glamorous areas if not the most obvious too, where science and technology impacted on man is with regard to the development of machines. Machines are able to utilize little effort to execute a work of infinitely greater scale. Hence $\mathrm{MA}=\mathrm{L} / \mathrm{E}$. In most machines M.A is greater than 1 (one) showing that less effort is needed for greater loads and/or work.

(vi) Through the knowledge of the principles of Density and Relative Density; pressure in liquid; Archimedes principle of floatation, and Faraday's laws of electricity, many inventions were possible ranging from the construction of bridges, Ocean Divers jackets, construction of force pumps, ships and electric current availability were assured.

It might be interesting to look at a couple of sectors where the modern society has most radically advanced in scientific and technological genius:

(a) Transportation - it is fashionable to hear the slogan 'good evening in Nigeria, good morning in London!' This is the miracle of the transport science. Obstacles of the high-sea, mountains, and unimaginable distances have been elliptically assaulted. With the airplanes and naval vessels the myths of altitude and depth have collapsed. With rockets, adventures have been made to the moon and other planets and possessory rights 
like flags established there. Notice also that more safety devices as air bags, et cetera, are being devised daily.

(b) Climatology - today, men determine weather and seasons at their private caprice. With air conditioner, and heaters, the effect of inimical weather changes has been 'rounded up'. Even natural disasters can be predicted with sensitive instruments and either averted or made less disastrous. ${ }^{27}$ The recent hurricane bash that struck America is a case in point.

(c) Medicine - some diseases which hitherto were grossly lethal have been relegated to the insignificant effect of temporary indisposition in health as follows: Malaria, Rabies, even HIV and today Avian Flu are now handled with expert knowledge and care. With immunization some illnesses would not even indicate. What is more! Epidemics are anticipated and prevented (Guinea worms). All too interesting were the advances made in clinical psychology and psychosomatic medicine.

(d) Communication - this is the fashionable thing today. It is the state of the arts to be connected and to be online. Telephones, handsets, computer microchips, etc., have developed the information super-high ways making the traffic quite heavy today. Posting of letters is obsolete, manual typewriter is obsolete, telegram too. It is fashionable to talk of e-mail, e-learning, e-voting, e-banking, eresearch, we even have e-loving who knows whether the next engagement will be with e-eating (EE). With all these, the world has been globalized into a village. Though expansive, it is sensitively intensive. This is critiquing the African communalism. ${ }^{28}$ Space and time have been encountered and needed re-definition.

(e) Banking and economics - here we have the use of credit cards. Slot it in, pick your money and go!

(f) Agriculture and Industry - agriculture in the New World is mechanized. It is no longer at the subsistent level. Man's production and marketing have taken a great mechanical leap. Also with improved storage and processing facilities we can process and store for non-viable seasons. In this way, famine becomes a myth. 
The miracle of these technological feats is that time and energy are saved for constructive investment, yet much work is done. Look at this scenario: when publishing was limited to hand copying, it might take months to copy quite a large volume. But "after Gutenberg's invention of movable type in 1456, 40,000 printed works were published within a single generation." 29 That sudden availability of information generated an explosion of learning that has been sustained to this day. ${ }^{30}$ Nicholas Copernicus by this was able to read extant Greek works and so wrote De Revolutionibus where he re-presented the Heliocentric theory.

\section{Stage of Absolutizing Science}

From the $20^{\text {th }}$ century it appears that the ecstasy of accomplishment has overtaken the scientists. Thus the bid is today on the path of making science absolute. Preparation for this was made by the farreaching successful explorations which science had in the outer world i.e. neighbouring planets and in the inner world "the structure of subatomic realities." With this, some air of infinity and omnipotence masked the project of science.

Having exhausted 'the within-reach', descended into the depth of the atom and further ascended to the heavens with the rockets, science now appear to some people, the god of the new age. Like the incarnate Christ who was Emmanuel with us, took flesh, descended into hell (descenssus ad inferos) and ascended into heaven. Analogically therefore, science seem to have completed the cycle of "divinity." Obvious outline of this stage was the bold attempt to reduce every reality to the scientific measure and categories, not excluding life, values, morals, spirit, culture, and language to logical atomism. Pragmatism, process philosophy and process theology were, in like reductionistic spirit, packaged and advanced to the people with so much ideological bombardment as if they were all that is about reality. The scientific Weltanschauung is thereby the leading voice and guide in the technological society of today.

In spite of the scandal of this reductionism, it has some advantages though: Under this atmosphere, unencumbered by any consideration, scientific engagement was free and unrestricted, and science thus ventures into no-go areas as with genetic engineering; 
talk of stem cell researches, cloning! Again, these feats achieved in these areas have continued to raise fresh questions of scientific, religious, moral and spiritual importance. Were these 'profane' liberal and heterodox inquiries not made, mankind would have been nevertheless denied certain necessary facts, much as it is equally preposterous, in the alternative, to sacrifice humanity on the altar of knowledge or facts! One needs only to evaluate the net significance of the new physics that emerged at this stage - the quantum physics - to see its concomitant advantages and equal paradoxes.

\section{A Review of the Intellectual Impacts}

Equally impressive as ever are the intellectual attitudes excited by the scientific worldview, which was to develop into a methodology. Any properly scientific temper facilitated a rising above utilitarianism, which was inevitable at the stage of survival, and characterized by techniques. This is because it promoted and sensitized the mind towards understanding observed facts and seeking out their causes. ${ }^{31}$

Scientific epistemology was out for demystification of knowledge in counterpoise to erstwhile sub-scientific provenance of myths. Natural explanation was sought for natural phenomena without resorting to magic and mythology. Thales was the first in recorded history that resisted the all too common appeal to gods in explanation for the fertility of the earth. He explained earthquake by the movement of subterranean rivers shaking the ground and not by the rage of Poseidon (god of the sea). Lightning was accounted for by wind cutting through the clouds rather than by the ill humour of Zeus-god of the thunderbolt. ${ }^{32}$ Thus "one of the ambitions of the preSocratic natural philosophy was to free scientific explanation from supernatural interference and caprice of the gods",33 and to inaugurate a new logical progress from cause to effect and vice versa.

The gnoseological status of man as an observer of scientific events has become monumental and evident given some insightful perspectives in Quantum Physics. By looking at the world from different angles, scientists have provided fresh insights and new perspectives of man and his place in the universe. ${ }^{34}$ The New Physics has indicated that man is not a passive observer but one who 
has biases and prejudices which go to determine the direction of the result. Hence "in giving lectures and talks on modern physics, I have discerned a growing feeling that fundamental physics is pointing the way to a new appreciation of man and his place in the universe." 35

As a matter of fact, a phenomenon under scientific observation is now known to be defined by an indivisible whole consisting of the system, the observer and the instrument of observation. By this, the object observed and the subject observing become inseparable. The result is that knowing becomes an act of participation and "things only take on meaning when filtered through human experience." 36 What the New Physics has indeed shown is that man is not a passing participant in the world. Even his position as an observer of the quantum event is determinant of his result, more so his measuring device and environment are prejudicial to the result. Ready to carry out any experiment, man comes with his ideas, his biases and prejudices; these compose into basic presuppositions. It is against this backdrop that he chooses his data and conditions of experiment. All these tele-command the end results of his design, no matter how imperceptibly. Thus, Physics has given "the observer a central role in the nature of physical reality." ${ }^{37}$ Nor is this temper limited to a quantum environment; not at all. What the New Physics did with the observer was to reinforce an insight already indicated at the emergence of the scientific spirit in the modern times, and having subjected it to further and rigorous study, discovered its profundity and vast implication. Hence, that the scientific spirit was minded to raise the status of man and to exalt man to a very high estate, placing him at the heart of reality was already evident in the Cartesian philosophy which was the originating source of the scientific spirit in the Renaissance. In his Discourse on method, Rene Descartes presents the world with a quasi philosophical formula beginning with the idea that nothing can exist outside the consciousness that I who do the doubting exist. He constructed a logical system to the effect that: "I think therefore I am." This was to form "the basis for a philosophy of life which took into account the intellectual achievement of the last century and a half... it regarded man as the starting point of things, thus reversing the medieval order.",38

By and large, the success with which man, with the scientific instrument is able to control, explore and exploit nature is indicative 
of an important metaphysical phenomenon viz. the autotranscendence of man. If man were to be at the same level of reality with mere nature he could not rise above it to explain and order it. This is for the fact that scientific progress is of the nature of making matter consistent. And in order to make a system consistent, one needed to be inconsistent with that system. Gödel's theorem shows that from within a system it is rather impossible to prove the consistency of same. Hence "no complex formalized system can find within itself, either proof or refutation.",39

Science and its worldview have been quite significant in the mankind's battle against dogmatism of sorts. The pre-historic man as for the man of the medieval church is often than not given to fixed points of view; not much room is open for dynamism and contingency. On the other hand, the man of science is ever ready to shift paradigms. If a theory fails to explain a set of facts, it is not the case that such dogged facts are thrown away rather, the theory is either changed or adjusted to accommodate the new facts. Hence, central to this approach is "the willingness of the scientist to abandon a theory if evidence is produced against it... the scientific community is always ready to adopt a new approach." 40 A classical example of this temper is shown in the way in which the world shifted from the 'almighty' Newtonian physics and its constructs for those of Einstein and Max Planck. Newton's infinite-universe model from which his laws of mechanics were drawn was cast concrete. It held the world for over a thousand years unto a great emotional rapture and rational appreciation. However, all too sudden, the Josef Steffen's head transfer experiment, Friedrich's gravitational potential paradox, and Michelson's Morley experiment began to indicate grievous weakness of that Newtonian world. All attempts to defend the later were failing. It was left for Einstein to give it a final blow with his Special Relativity equations, and then the world shifted camp, abandoning the Newtonian Universe. The implication can only be described as monumental. This is because "Atheism, Darwinism and virtually all the "isms" emanating from the eighteenth to the twentieth century philosophies" which were built on the assumption that the universe was infinite collapsed. ${ }^{41}$

There is a sense too, in which scientific worldview was instrumental in persuading the world away from an all too 
unnecessary adulation of authority. This created a frame of mind that was to move the world forward. Appeal to authority was the official attitude of the medieval world. Authorities were dogmatically preached and zealously defended even when they are in error. At the dawn of scientific age, then, "practical experiment replaced authority as the deciding factor in scientific truths." where authority ought to be appealed to, assent was no longer credulous but emphasis was on experts capable of demonstrating evidence for the said claim. The clearest example was the case according to which the Aristotelian and Ptolemaic planetary systems, which were geocentric, commanded intellectual obedience of generations without questions. This was speculatively devised to valorize the "invariable" belief that man is the centre and chief of creation. In fact, the medieval church felt that to displace the earth from the centre of the universe will outwork far reaching implications both for theology and anthropology. When Nicholas Copernicus, in his De Revolutionibus, provided a Heliocentric vision which proved more convincing, the Protestant and Catholic churches became embattled for the reason that the new ideas are threatening to overturn the traditional concepts of the universe vis-à-vis man's choice-place in it. The Protestants, for one, shouted foul saying that the hypothesis has opposed the authority of the bible. Though the said book was dedicated to Pope Paul III, the Catholic Church nevertheless placed it on the index in 1616 (AD) and its views were condemned as heterodox. Precisely because the scientific truth is resilient and cannot be couched to false submission, Galileo Galilei came in with his telescope and after due observations came out with a series called the two principal world systems which showed beyond doubt that the Copernican hypothesis was intellectually superior to its forebears despite the authority the later had disposed. Immediately, the inquisition followed him. Notice that this intellectual attitude of 'testing in order to believe' became a principal canon for all forms of knowledge not excluding spirituality where there is emphasis on discernment of spirits much more than in the biblical and medieval times. The point is that from the scientific bang, "Practical experiments replaced authority as the deciding factor in scientific truth. Thus, both Galileo's rejection of the Aristotelian planetary system and Harvey's discovery of the 
circulation of blood represented the refutation of ideas which had governed man's attitude to life for centuries and so showed new and startling avenues in astronomy and physiology." the ongoing process in the empirical sciences which it has bequeathed to the vastness of world cultures that "when data are more fully understood, then, results the emergence of a new theory and the rejection of previous theories."

Today, it has been widely accepted that scientific progress contributes to the development of the theory of interpretation Hermeneutics on its present footing. The classical event that contributed to this development was still the 'Galileo heliocentric arrogance.' Soon after the Renaissance scientist published his findings, the Church authority was piqued. How can a layman challenge the church's interpretation of the Scriptures? Then, Galileo took opportunity to answer while writing to the Benedictine monk "the Holy Scriptures cannot err and the decrees therein contained are absolutely true and inviolable. But ... its expounders and interpreters are liable to err in many ways; and one error in particular would always be most grave and frequent, if we always stopped short at the literal signification of the words." 45 Interestingly, Galileo brought out the scriptural pericopes in question as Psalm 93: 1 and 104: 5 and Ecclesiastes 1: 4-5. All these are to the effect that the earth is immovable. Through a mathematically strengthened hermeneutics, Galileo was able to show the world that no matter at what speed the earth moves, any observer within the earth must experience and account for an immovable system. The reason as gleaned from his calculations is that if the earth is moving at velocity $\mathrm{V}$ relative to the sun for example, then its movement relative to itself is $\mathrm{V}-\mathrm{V}=\mathrm{O}$. Hence, anybody from an earth bound observation must give an immovable account. Thus all the passages in the bible were speaking from an earthbound frame as their background. In this way Galileo was "emphasizing how essential it is to establish the frame of reference when conducting any scientific or exegetical inquiry.", This has long been extrapolated such that today all theories of interpretation take seriously the question of frame of reference.

The world and human affairs were further conducted into grave fatalism through the logic of a world populated by capricious divinities that, as it were, fix the destiny of men and by their 
ominous power pre-destine the universal regularities. But above this, the Newtonian Universe, which was of great influence in the tide of scientific era, fostered a worldview, which is overly characterized by order, regularity, and apparently immutable laws of nature. With the dawn of Quantum physics, a whole reversal of this cast dawned. Hence, once it was held that "science was certain knowledge" of things through their causes, but in the quantum era, science is no longer certain but deals with the statistical and probable. "It attends to data rather than things. It speaks of causes but it means correlation and not end, agent, matter, form." Once, it was held that science is concerned with the universal and the necessary. Today, in Mathematics, necessity is a marginal notion: "Conclusion indeed follows necessarily from their premises, but basic premises are freely chosen postulates and not necessary truth. ${ }^{, 47}$ Notice that before it was fashionable to speak of necessary laws of nature and even of the iron laws of economics. Quantum Theory and Keynesian economics have put an end to that. The point of revolution started when Max Planck broke into the subatomic matrix allowing Heisenberg and Schrödinger in their uncertainty principle to find that the position and velocity of the electron about the orbit cannot be determined because of the wave-particle duality behaviour of the electron. If there is such freedom in the subatomic level upon which macro-systems are built, then the myth of determinism has collapsed in a large scale. With this discovery marketed, the world now thinks more in terms of freedom than deterministic worldviews. What is more! The whole issue of free thinking and autonomy of perspectives have been popularized.

Pragmatic thinking and of truth has been valorized by the strength of scientific progress. Indeed, of the three classical theories of truth (i) correspondence (ii) coherence and (iii) pragmatic theories, the latter has become the common criteria today. It is not for any other reason than the fact that pragmatism is the spirit and language of the scientific revolution. Science is minded on workability, satisfactory consequences and utility value. The content of the pragmatic criteria was generally drafted by an article of Pearce's which appeared in 1878 entitled "How to Make Our Ideas Clear." From the article, the temper of pragmatic thinking is seen to consist of the "tangible and concernedly practical." ${ }^{, 48}$ Since science 
has claimed superiority in all knowledge fields, it has stiltedly imposed the pragmatic criteria into every sector: pragmatic philosophy which may cover the whole vistas of process philosophy, instrumentalism, all forms of empiricism, and all forms of positivism, logical atomism and secularism. Theology, economics, politics, culture, language and all that, today defend the pragmatic temper. And, it appears a welcome intrusion into the world's epistemological sensibilities since it has engendered some practical usefulness indeed.

It is important to focus reflection on the impact of science on man's vision of reality. According to Lon champ, in his Science and Belief, "The main scientific advances in the twentieth century undoubtedly give us a new vision of science and of the world. Likewise, they enable some major philosophical questions, notably complexity, reality and rationality to be phrased better."49 Popular philosophies have long taught that reality is about "the whole of that which "is" or "exists". In this remarkably impersonal milieu, objects "are endowed with real properties" and described without reference to any matrix not even the human mind. At the instance of the quantum revelation, reality now becomes "a collection of known phenomena", based on the "consensus of the scientific community". What is more? The description of reality, though arguably inadequate, relies almost exclusively on mathematical concepts. This new approach widens the scope of what can be termed reality (parareality and independent reality are included) and at the same time gives essential place to the human being as an observer and experimenter. ${ }^{50}$

\section{Metaphysical Impacts}

It has been an issue of wild conjectures whether the scientific progress has got any welcome implication to the metaphysical world; whether the human sensibility for the spiritual and metaphysical has been affected or promoted by the centuries' scientific strides. Lon champ has aptly recommended and it is worth observing that "we must recognize as the basis of all broadly scientific work an almost religious conviction since it accepts a world founded on reason, an intelligible world. This conviction, 
linked to a deep sense of a superior mind reveals itself in the experimental world." 51

The logic of the above scientific progress could translate for any keen mind, the idea of God. Indeed, order is an attribute of the intelligible, and from the metaphysics of order, access to the supernatural realm could be realised. Hence, in the presence of and confronted with the profundity of order lavished in science and technology, the human spirit immediately reaches out to the "wholly other" in the non-material horizon. The cosmological argument for God's existence especially as adduced by Aquinas (quinqua viae), is thereby a philosophical-scientific recipes seeking to unravel what lies beyond the empirical reality.

Albert Einstein once said that if the proposition of science ever succeeds, then it is indicative of an underlying reality to the phenomena. Saying this, he is subscribing to a reality "existing independently of all observation" or measurement and residing outside space and time in an eternal and infinite region. In the structure of reality fashioned by Bernard d'Espagnat in the light of quantum mechanics, two distinguished but not separated aspects of the one reality is highlighted as follows: empirical and independent reality: While he referred to empirical reality as "all phenomena" having structure, regularities and laws discovered through unceasing scientific work; independent reality forms a whole, situated outside space-time context. According to d'Espagnat, this reality behind others leaves invisible traces in our world of experience. The regularities observed at the level of phenomena are reflection of the regularities of the independent reality. What has been designated as independent reality is interestingly the horizon of being: Spinoza has called it "God"; Emmanuel Kant designates it as "reality in itself"; d'Espagnat denotes it as "the reality behind things." As if by some tincture of analytic consensus, philosophers have referred to this reality as a matrix, thus giving it an original causative capacity. In this way they regard as the matrix of all phenomena and of all values, the sacred, the holy, the wholesome and all. Hence, when the artist contemplates mysteries, 'something' hidden behind these sensible signs, he is face to face with being in a metaphysical terrain. Suffice it to say that the classical extemporization of the inventive genius of a scientist in creation reveals being as much as the 
theological thought of theologians or rarefied abstractions of metaphysicians at meditation. The fact is that "the metaphysical quest of being (or God) needs to be posed beginning with empirical reality, and so, from science, by the search for the one in the many. The metaphysical procedure already glimpsed by the pre-Socratics is being rediscovered at the present by eminent scientists reflecting on what they are learning from contemporary science." ${ }^{, 52}$

It is also fashionable today to find a rational trajectory, which leads us from scientific cosmology to metaphysics. An example of such travelogue is what has been popularly called the anthropic principle. Expert opinion suggests that, were certain constants of physics to be otherwise, life, and indeed, man would not have seen the light of existence at least in this known universe. This "our universe is therefore a very special one by reason of its initial conditions." Everything appears to have been designed by an exterior intelligence having man in contemplation. The New perspective in physics, by this, alerts us to this idea and thought that man is essential to the creation of the universe as the universe is to the creation of man. ${ }^{53}$ Notice that by these new insights, more scientists are now prepared to see in their project the evidence of another world. They "now do not hesitate to raise... in their works, basic metaphysical questions." 54 Here, then, lies the signum temporum (sign of the time).

Science has brought not a few people in the modern times to a religious condition of a special type. Many people who have found the traditional religions unattractive, by the fact of many unexplained experiences, have turned to fringe religions, which try to give scientific interpretation of religious faith. This is concordism of special type. But at least what is interesting is the symmetry, which some people were able to discover from science to metaphysics. Starting with scientific attractions they end up with a spiritual repose. Thus "the huge rise in popularity of cults associated with UFO's, ESP, Spirit contacts, Scientology, transcendental meditation, and other technology-based beliefs testifies to the continued persuasiveness of faith and dogma in a superficially rational and scientific society. For although these eccentric ideas have a scientific veneer, they are unashamedly irrational - "cults of 
unreason" ... people turn to them not for intellectual enlightenment but for spiritual comfort in a hash and uncertain world." 55

Perhaps, even if only "Via Negativa", the many unexplained gaps in science are signs of iridescence of the metaphysics behind the veil of the empirical: the Case of the causative principle of the big bang of scientific Cosmo-genesis; the missing link in the theory of evolution. These and more dark-visions in scientific knowledge may serve as a veritable invitation to the metaphysical for explanation. This is the issue with the much orchestrated God-in-thegaps theology. Not withstanding the fact that this orifice to metaphysical/theological abstraction has been dismissed as representing another popular misunderstanding of science and religion, ${ }^{56}$ it has enchanted not a few to a rational evidence of events at a meta-empirical horizon.

Over and above this, a section of men of science had no qualms acquiescing to the probability, indeed, the fact of an intelligent supra physical mind designing and executing the symbols of science. Such broad minded fellows, who were happily also at the vanguard of Scientific revolution were all devout men, both of religion and science - Copernicus, Galileo, Tycho, Kepler, Newton, even Descartes and Francis Bacon. For those, God not only created the universe, but also had continually maintained its order and harmony via agencies. Little wonder the scientific and theological communities were at peace up to the middle of $17^{\text {th }}$ century, during which it was possible for men to hold dual appointments in both astronomy and theology."

Regarding the metaphysical anxiety of some men of science, particular mention needed to be made of Einstein. His equations of Special and General relativity forced him to accept the necessity for a beginning for the universe and eventually to "the presence of a superior reasoning power" though not a personal God. ${ }^{58}$ Einstein had once confessed that between the abstract formula and the material conclusion leading to great feats in science, there is always an elliptical jump provided by the mind behind things. It is always the "Why?" of the experiment, which no investigation into the "How" can ever, reveal. In the words of Colins Gunton in his "Knowledge and Culture: Towards an Epistemology of the Concrete" "in producing its ideas, the mind moves beyond its previous 
achievements by a creative leaps... ${ }^{, 59}$ Einstein personally witnessing to this creative leap see concepts as free creations in the sense that they are readable neither from the human mind nor directly from reality. For him, that is the sense in which all knowledge is the gift of the creator Spirit.

\section{A Brief Survey of the Negative Impacts of the Scientific Dominion}

Science may have alleviated the miseries of diseases and drudgery and provided an array of gadgetry for our entertainment and convenience, but it has also spawned horrified weapons of mass destruction and seriously degraded the quality of life. The impact of science has been a mixed blessing. ${ }^{60}$

With these opening lines from Paul Davis, the best seller cited earlier, the stage is set for reflections on the sordid implications of the exaggerated scientific progress.

1. Man and Work - The industrial revolution was immediately accompanied by the mechanization of work. Manual imputes were gradually being put off by mechanical appropriation. The result of this was that machines displaced men from work. Unemployment is created and even though there have been welfare provisions for the unemployed, a deep philosophical problem of satisfaction and fulfillment of man as animal laborens and homo Faber emerges to the fore. Work is done by man not merely as a means of fending for himself - feeding, etc., but as a source of an "ecstasy of accomplishment" arising from the fulfillment of his being. Little wonder in legal sectors, to displace a person from work, even though you are paying him, is still actionable for he needs not just money but the work in order to live integrally.

2. Mental Relapse - Strong advocates of Darwinian biology have long advanced the idea that when an organ is consigned to disuse for significantly long period, it tends to be out of use and 
work completely. The multiplication of machines and computers in a technological society makes the human faculties to lapse to inefficiency. This is today more true of the brain where with the common domestic use of calculators and computers people are incapable of making minor arithmetic calculations. This is because since people can store information in the computers, nobody can again memorize small phrases or even phone numbers. Examples can be multiplied. The point is that technology tends to make native capacities redundant to a dangerous extent.

3. Logical and Practical Reductionism - The many and brilliant successful campaigns of science and technology have bombarded the society so much so that people have unconsciously lapsed into practical idolization of science. Recourse is made to science for an answer to even moral and spiritual questions, economic and political dilemmas etc. Instead of a methodological bracketing of other perspectives so as to achieve the best in it specially, it denies the reality of other perspectives. People now give to science by the force of its intimidation, the title of "the supreme knowledge" and exclusive answer to all questions. This is a lethal reductionism capable of outworking unimaginable dangers to the society. Examples of such excesses are represented by the terms psychologism, practicalism, instrumentalism, empirism, scientism, etc. Notice that a point of view is a point of blindness. When applied to anthropology, Matson did say, "Reductionists extend the method of natural science to the study of man. Their results accordingly, are valid only in so far as man resembles a robot or a rat and while such resemblance does exist, exclusive attention to it gives a grossly mutilated and distorted view. ${ }^{61}$

4. Change in the Concept of Death - Given the rare technicalization of warfare according to which high capacity instruments of mass destruction are amassed, we have passed from the idea of death of persons at war to a possible human 
holocaust. For example "before the thermo-nuclear bomb, man had to live with the idea of his death as an individual; from now onwards, mankind has to live with the idea of its death as a species." ${ }^{2}$ Indeed, with new war technology the effect of a possible engagement between world powers would be unimaginable. The office of Technology Assessment of the US. Congress studied the likely effects of a single IMT air burst over a city of four million people and results show that about 470,000 people will be killed at once and about 630,000 badly injured. This has excluded chain reactions of the warheads that will follow not excluding ecological accidents it will cause immediately. ${ }^{63}$ Added to this and connected with it, with such developments as airplanes, accidents today, claim lives in hundreds and thousands.

5. New Idea of Peace - It appears that today because there are no World wars, that there is peace among the nations. Unfortunately, mechanization of War has afforded us a new epistemology of peace no more as "shalom," justice, loving kindness, companionship, et cetera, but as absence of war. Alexander Solzhenitsyn has described the result as life under 'nuclear Umbrella'. With the bomb at the background "there has been no war between the superpowers. The bombs have produced a form of pacifism, because nations are reluctant to confront each other for the fear of nuclear weapons being used. This has meant that sometimes injustice has gone unchecked for the fear of starting a war." ${ }^{64}$ In Guadium Et Spes, the Fathers of the Second Vatican Council have in no. 78 objected to this state of perpetual anxiety of nations. It asserted that "peace is more than the absence of war: it cannot be reduced to the maintenance of a balance of power between opposing forces nor does it arise out of despotic dominion, but it is appropriately called "the effect of righteousness."

6. Globalization - It is no longer news that the world is today fast rescinding in the direction of becoming a global village. Scientific progress through the inauguration of the information 
super highways or the Internet has broken barriers of distance. Anything happening at one part of the world becomes an issue simultaneously at another. Although this scenery may not be assumed negative in its own right, yet, the concomitant eclipse of personal privacy of correspondence and communication or individual security of thought and information, and more, are indirectly impacted, or in the ethical parlance, willed by the trends of globalization.

Thus, the reality of space and time has collapsed more or less in a myth, such that distance and boundaries become anachronistic. The puzzle is that while the world is increasingly becoming committed to novel engagements by day, and thus expanding in material accretions and commitments, it is nevertheless, paradoxically but sensitively collapsing to a unity. Dangerous effects of this abound - security of information and indeed secrecy is collapsing with time and space as well. Other negative issues connected with the Internet have been raised: free access to unmonitored pornography and dangerous ideologies.

7. Spiritual and Religio-Moral Derogation - It is in this region that the negative effects of scientific progress were more sharply registered. Whenever and wherever in the progress of science the exclusion of God and God language was accomplished, every other negativity was not just a possibility but became quite imminent. As science became more and more successful, it began to forget its ancestral Christian anchorage (I shall rather say historical Christian alignment). ${ }^{65}$ It was, however, left for 'prophet' Nietzsche to publicly announce that God is dead. ${ }^{66}$ This death of God means the "demise of abiding moral verities as well." ${ }^{, 67}$ In the emerging scene with empty ethical systems, absolute standards of right and wrong and of good and evil are abolished. As it were, mankind is left forsaken and alone in a cruel and confusing environment without a compass. Here, the authentic man is one who accepts his God-like responsibilities seriously. ${ }^{68}$ Because to kill God is to become God oneself. ${ }^{69}$ The scientific man having 
overthrown God, the next stage is logically inexorable: rationality turns into rationalism in which man attempts to grapple his problems without an auxiliary beyond. With unfolding times, the implication and the weight of this new godlessness began to emasculate the whole sectors of human concerns and affairs. Moral and spiritual values gone, efficiency became the evaluator of all things. In the reign of the efficiency-criterion, matter was successfully exploited. However, not long ahead, it unleashed grievous consequences for man as the materialization of the object furiously engulfed the subject itself. Through the theory of evolution and the psycho-analysis of Freud, the human life and person were reduced to an ensemble of material collocations, 'objectified', 'thingnified', and exploited. Hence, the autonomous subject in his 'ungoded' condition was rent asunder. In fact, the very core of the human has entered into a morbid process of decomposition. This decomposition is now felt at all quarters of existence: in music, education, politics, literature, medicine, etc., making the world a technological society.

In such an ambience, a person's worth is directly proportional to his achievement. Accordingly, those who can make no meaningful contribution to the general welfare such as the senile, insane, incurable etc. are dismissed as invalid or burden. There is no other criterion of evaluation than 'scientificity', productivity and efficiency. The unbending logic of this whole reasoning is that the idea of a non-material future is but foolery and all reasons for selfconstraint abolished. In what follows, we shall attempt to outline some of the most sordid areas where this philosophy of blind expansion has manifested.

\section{Human Soul and Mental Engineering}

In this Brave New World as Huxley called ours, it is fashionable to pursue unethical experiments into the human biology. Most of these experiments relegate to the background, the static aspect of human person which defines man as man. Indeed those exploits could be defined as disrespectful exercise of elective discrimination into human integrity and dignity. Among these infamous and ethically 
unguarded "burglaries" are: Artificial Insemination (AIS or AIH), use of sperm banks, In Vitro Fertilization (IVF), unguarded stem cell researches, abortion for extraction of collagen in view of commercial enterprise, use of infanticide and euthanasia as tools of social engineering.

Attention needs be called to genetic engineering proper. In taking this direction, the scientist promises the illusion of ideal humanity. In the face of this, Watson observes that the code of life has been cracked and under the magic world of biology man is becoming quite different. ${ }^{70}$ The summit of this exercise in genetic manipulation is perhaps cloning, i.e. asexual reproduction of genetically identical human persons. According to Voice from the Vatican, this would lead humanity down a tunnel of madness. Alongside cloning are also exploits towards the realization of: ManAnimal Chimera (man modified with animal characteristics); Cyborg (A rational machine); and Geronotology (Science of human immortality)

Nuremberg reflecting on these meta-ethical problems raised an alarm to the effect that man may be able to programme his own cell with synthesized information, long before he will be able to formulate goals, and long before he can resolve the ethical and moral problems which will be raised. ${ }^{71}$

\section{Behaviour Modification}

This is another sector where some of this ethically hollow, and therefore, horrendous experiments and manoeuvres are exercised. Even in some supposedly Christian circles, behavior modification techniques are taking the place of conversion of souls; a context in which scientists wildly probe the inner recess of human identity, personality and individuality, changing it unto utilitarian purposes. Communist states were at the vanguard of such weird attempts. There, "psychology and psychiatry" easily became tools for bringing conformists into line with the general social consciousness or the dictates of the state. ${ }^{72}$

Pavlov first practiced something like this with his dogs, and perfected it with humans. He was able to arrive at techniques capable of shattering the established patterns of human personality so that "the fragments could be integrated into a new structure of 
memory, judgement and emotions in line with the desires of the communist craftsman." 73 Practitioners usually achieve this by the method of mental breakdown called cortical inhibition of the higher cerebral functions. It involves a process of exhaustion, confusion, chronic physical pain and emotional tension (fear). With this, those sustaining deviant ideologies in a 'scientistic' society are immobilized.

All in the name of medicine today, high powered electrodes are borne into the skull, commissioned to harass the human brain on experimental feats. In the University of Tulane, for instance, fourteen electrodes were permanently implanted into the brain of a 28-year-old man. This, it is claimed, will provide a control for his endemic sleepiness. ${ }^{74}$

Surprisingly, chemicals - no longer re-orientation or change of habits - are today being employed for behavioural change. There are a host of drugs that alter emotions, change feelings, modify behaviours and even change personality when they are applied to man. Such drugs as hallucinogen (mind expanders) and cataplexogenics are domestic intakes.

Recently, Prof. Peter Karmmer announced the development of his cosmetico-psycho pharmacology. Through this, drugs that mutilate temperaments are available. It is simple: follow the doctor's prescription and go for a new temperament. ${ }^{75} \mathrm{D}$. Alexander, in his Beyond Science, strictly observed that "never before has man held such powers in his hands. Never before has there been such a great temptation to misuse it.",76

\section{Education, Politics and Security}

Any proper education must address man in his tripartite dimensions of body, mind and spirit. But 'scientistic' education and education in a technological society attempt to be prejudicial to transcendence. This aversion for the non-material is making education to be more and more lopsided in favour of narrow provincialism and sly materialism. What is advanced in the new world is education for utility and efficiency. Our educational programmes develop an ethic which has no supernatural sanction. ${ }^{77}$ America, for instance, popularizes instrumentalism or experimentalism as an official education theory. With its pragmatic spectacles, it is blind to the 
spirit, and responsive only to what is material in man. ${ }^{78}$ Since instrumentalism shuns supra-sensible dimensions to reality but grounds itself in the 'experimentable', pragmatic technology outrightly replaces religion and poses itself as the only option. Yet this is lethal. ${ }^{79}$

\section{Conclusion}

The many benefits of science notwithstanding, were the scientific ideology to be allowed its desired opportunity, the consequence would be destructive of the aesthetic world of reality. Notice that the scientific temper which took shape in the dawn of $17^{\text {th }}$ century soon became in the hands of Comte, a cult ousting all religious truths as outdated prejudices making the scientific the only source of truth and reality on which human destiny can safely be constructed. Particularly, Ernest Renan (1823-1892) prophesied that the 'scientototalitarian' organization of humanity is the only legitimate expectation for the world's 'salvation'. This vision was to be perfected in Berthelots' case for scientific superiority according to which scientists will have to take over the natural, intellectual and moral direction of the society. What appears compelling in all these is that discovery (Galileo), creation and productivity (Marx), and indeed change (Bloch), have by the force of science become superior alternatives to religion, values, contemplation and arts. Permanence becomes an inferior category to change.

Basic outlines of this technological society was being accomplished when Galileo in a passionate indignation vented that if nature did not voluntarily answer our questions, we shall in wracking inquisition extract answers from it. These answers to be extracted by duress will compose into the real truth, which joins with the material act for creating a world worthy to live in, as Karl Marx saw it. A cumulative sediment from all these was articulated by Ernest Bloch in these words "truth is now whatever prevails", making reality "a signal to invade and an instruction to attack," for the purpose of changing, subduing and making a new creation. In this way Francis Bacon's humble disposition towards unveiling the volume of creation is lost and "a new earth and a new heaven of the book of revelation loses the sense of an eschatological promise but becomes an immediate expectation from the scientific El dorado." 
Nowhere else than in the Hebrew Scriptures can we find a better explanatory framework and integral inspiration for scientific progress; for there is no doubt that the cause-effect rationality of the scientific enterprise was a complete carrying over from the biblical doctrine of creation. Yet, though the bible gave evidence of some material causality when God has to mould the earth pursuant to creating man, it went further to show that formal and final causes are implicated before creation could be accomplished. Hence God "breathed into the earth" and "said..." In that same first book of the Sacred Scriptures (bible), something of a scientific imperative was given - "subdue the earth". Any unguarded construction of this clause would likely find a strong basis for the scientism of today. This is for the reason that the infinitive "to subdue" smacks of exploitation, materialization, malleability, mere utility employment, to the exclusion of any sense of preservation, honour and respect due to creation. And so starting with that originating clause, the world wars, Hiroshima and Nagasaki holocaust, the Nazi scandal and their likes would fall in place. And it would rather be surprising why God distracted the ambitious project of Genesis chapter 11 which was intent to subdue creation and through the Tower of Babel access the infinite and the heavens.

But observe that Genesis 1:29, which reads "subdue the earth" was limited and defined by Genesis 2:15 "till it and keep it". Therefore, for the purpose of human experimentation, stewardship and creativity, "subdue the earth" becomes in pari essence with "till the earth and keep it". Keeping this in view, the apparently honest scientific ambition of Genesis 11 and the contemporary scientific temper appearing in positivism is theologically placed on the index. Joseph Ratzinger, ${ }^{81}$ explaining this creation imperative given to man, observes that the creative directive to human kind means that it is supposed to look after the world as God's creation and to do so in accordance with the rhythm and logic of creation. The sense of the directive is described in the next chapter of Genesis with these words to till it and keep it.

And so a joint reading of relevant scriptural pericopes and relevant scientific temper would show that somewhere along the line, dominant science lost its proper focus and traveled on a rudderless course charted by principles dictated by contingency and 
dry empirical progress. Hence, the problem does not concern nor does it relate to the epistemological content of the sciences. It rather rests on the reductionism of fanatical and over zealous scientific researchers who unduly extrapolate the scientific conclusions into the vastness of life and existential concerns. In this blind fellowship, they see in scientific progress both the diagnosis and therapy to whole life problems. This is arrant naturalism or materialism leading up to atheism. Engaging the indefensible position of such a scientist, Philips in his God Our Contemporary has this to say; "To him (the blind scientist) all that art or religion or philosophy has to say is really quite beside the point, science will lead him by sure and certain methods to heaven upon earth." ${ }^{\text {" }}$ At any critical level of consideration, such stance as above is implicated with an illusion of omnipotence and/or omniscience. Whichever way, it is a grave deficiency and error. Significant representatives of this worldview include Descartes who said "Give me matter and motion and I will construct the universe." inspiring such ideas as the above does not contemplate that in the region of arts, humanities, religion and philosophy, the empirical sciences are disabled by paralysis. Thus, because science can answer so many of our 'hows?' we should not be deceived into thinking that it can answer any of our 'whys?' While science struggles to investigate the mechanics of the world processes, the world's most instinctive question is 'why?' the question "why?" goes beyond the draughtmanship of heavens. It is in a different dimension to the physics and chemistry of process... it is a philosophical question insufficiently addressed in unlocking the secrets of the cosmos and its beginning." 84

An inevitable consequence of investigating only the 'how' questions is that science tears apart 'facts' from 'motive', 'mechanism' from 'meaning' and the 'external' from the 'internal' models of explanation. It finds its satisfaction exclusively in facts, mechanism and external processes. But one thing arguably certain is that science by its methods can never give more than one aspect of the truth about reality. ${ }^{85}$ All of mechanism and meaning, facts and motive, external and internal processes must be read together. In effect, the true place of science in the mighty framework of existence consists in accepting that: 
There are ways of apprehending some kind of truth, which are quite independent of the scientific method. Sometimes, these are intuitive and sometimes, they are developed by long practice and of course sometimes both....

Where this is put in perspective, the scientific method would consist objectively in refraining deliberately from certain horizons of occurrence in order to effectively handle a limited aspect of reality with the expertise of a specialist. It makes a preferred abstention from a more vertical and variant theorizing in order to properly and practically engage the horizontal phenomena. What this means is that, the precisely scientific project does regard as meaningless whatever is located outside the ambience of its operation and competence. Its work is to describe with symbols, not what happens as such, but what the scientist observes. Therefore, when new facts fail to satisfy existing theories, a paradigm shift will occur either by adjusting the theories or replacing them with new ones. Thus, there is no point at which the existing scientific theory adequately and finally explains the universe with its categories. The infamous departure to such a perilous position came with the contemporary 'metaphysics' of materialism which treats Ockham's razor, not just as a methodological device but as the sole tool needed to describe the world. ${ }^{87} \mathrm{~A}$ hard cast exponent and leading thinker of such extreme persuasion is Conrad who wrote that "science by itself is able to provide self-consistent and harmonious principle on which our material progress depends." 88

In this vain, the panacea for this error of excess suggests itself namely, the reintegration of scientific knowledge, at least in principle, via the re-education of science theories. This will consist in a re-orientation and re-focusing of scientific thinking and researches. Education of science, for the purposes of this essay, requires a revolution of a sort. By this, the scientific society, hitherto benumbed of value and spirit, will be sensitized to these realities by a re-education process. Not every kind of education suffices, but one which, according to Russell, increases through knowledge our appreciation of existence, ${ }^{89}$ one which, according to Okolo, has been 
imbued by sound philosophy of the ultimate goals of men and the society at large. Such education will not aim at destroying the specialization of science but revert it to its original inspiration of preserving the earth alongside its varied richness and values cultural, religious and otherwise. With this, the "the cause-effect" indices of the sciences which it took up from the creation narratives will no more lead to suffocation of the aesthetics and net-values of the created order, but to an ever fecund extemporization of possibilities. 


\section{Refernces}

${ }^{1}$ Genesis 1:26-29 (Jerusalem Bible)

${ }^{2}$ From disorder to an ordered world.

3 It was S.W.F Hegel (1770-1831) who popularized that ancient idea that man is unspecialized by nature. The purport of this proposition is that there is an infinite possibility open for man's improvement on whatever he does. Unlike the birds of the air that unfortunately are determined to fixed "skills" man is dynamically open to new forms and styles. Example, each species of bird has a non-improvable form in which it structures its nests. It is a closed system, but man changes the architectural structure of his house with each passing new ideas and necessity.

4 'Libido dominandi' is a medieval usage which refers to the egotistical and amoral desire to dominate nature and the other men with the instrument of scientific knowledge. As John Passmore has written, Kierkegaard wrote, "to handle the spirit of man in such a fashion is blasphemy" Cf. Kierkegaard, quoted by John Passmore, Science and its critics (London Duckworth, 1978, p. 181).

5 Josef de Varies, "Science" in K. Baker (ed.), Philosophical Dictionary, Washington, Gonzaga University Press, 1972, pp 360-361).

${ }^{6}$ W. Brugger, "Physical" in K. Baker, op. cit., p. 309

${ }^{7}$ N. Junk, "Physical Science," in K. Baker (ed.), op. cit., p. 309.

${ }^{8}$ W. Brugger, “Technology"”, in K. Baker (ed.), p. 411.

${ }^{9}$ Gaudium et Spes No. 12.

${ }^{10}$ Ibid., No. 14.

${ }^{11}$ Ibid., No. 15.

${ }^{12}$ J.B. Lotz, "Man” in K. Baker (ed.), op. cit., p.236.

${ }^{13}$ Ibid., p. 237.

${ }^{14}$ Loc. Cit.

${ }^{15}$ Cf. Josef de Vires, "End” in K. Baker (ed.), op. cit., p. 110.

${ }^{16}$ M.D. Aeschliman, The Restitution of Man, in B. William, Michigan, Ecrdmans pub. Co., 1983, p. 79.

${ }^{17}$ Ibid., p. 80 .

${ }^{18}$ Huxley, Ends and Means, London, Chatto and Windus, 1969, p. 252.

${ }^{19}$ M.D. Aeschliman, op. cit., p. 45.

${ }^{20} \mathrm{~B}$. Mondin.

${ }^{21}$ Lewis, The Abolition of Man, New York, Macmillian, 1960, pp. 44-45.

22 D.M. Mckay, The Open Mind and Other Essays, T. Melvin, (ed.) Leicester, Interversity Press, 1988, p. 83.

23 J.P. Lonchamp, Science and Belief, Maynooth, St. Paul's Publications, 1993, p. 9. 
${ }^{24}$ Ibid. p. 11.

${ }^{25}$ P. Davies, God and the New Physics, New York, Simon and Schuster, 1983, p. 6.

26 Cf. A.F. Abbort, Ordinary Level Physics, London, Heinemann Educational Books, 1963, p. 1-574.

${ }^{27}$ Cf. H.J. Critchfield, General Climatology, New Jersey, Prentice-Hall Inc., 1974, p. 1-412.

${ }^{28}$ African communalism was built apparently on (the idea that it is) a private preserve of the African peoples. But the great wave of globalization and its effects is showing that with changed conditions and circumstances the dialogical capacity to live together and share is very likely to arise.

${ }^{29}$ T. Rudolf, And There Was Light: The Discovery Of The Universe, New York, Alfred. A. Knopt, 1957, p. 73.

${ }^{30}$ H. Ross, The Finger Print Of God, California, Promise Publishing Co., p. 20.

${ }^{31}$ J.P. Lonchamp, op.cit. p.13.

${ }^{32}$ Ibid., p. 14.

${ }^{33}$ Ibid., p. 18.

${ }^{34}$ P. Davies, op.cit., p. 3.

${ }^{35}$ Ibid., p vi.

${ }^{36}$ J.P. Lonchamp, op. cit. p. 124.

${ }^{37}$ P. Davies, op. cit., p. 9.

${ }^{38}$ V.H.H. Green, Renaissance and Reformation, London, Edward Arnold, 1952, p. 55-56.

${ }^{39}$ J.P. Lonchamp, op. cit., p. 143.

${ }^{40}$ P. Davies, op. cit. p. 6.

${ }^{41}$ H. Rass, op. cit. p. 42-50.

${ }^{42}$ V.H.H. Green, op. cit., p. 53.

${ }^{43}$ Ibid., p. 51-53.

${ }^{44}$ B. Lonergan, Method In Theology, New York, Herder and Herder, 1972, p. 325.

${ }^{45}$ B. James, Galileo: The Man, His Words, His Misfortunes, New York, Herper and Row, 1964, p. 76.

${ }^{46}$ H. Ross, op. cit., p. 21.

${ }^{47}$ B. Lonergan, op. cit., p. 315.

48 T.R. Garvin, "Pragmatism" in K. Baker, Philosophical Dictionary, Washington, Gonzaga University Press, 1972, p. 318.

${ }^{49}$ J.P. Lonchamp, op. cit. P. 117.

${ }^{50}$ Ibid., p. 124

${ }^{51}$ Ibid., p. 119. 
${ }^{52}$ Ibid., pp. 126-127.

${ }^{53}$ Ibid., pp. 129-130.

${ }^{54}$ Loc. Cit.

${ }^{55}$ P. Davies, op. cit. p. 2.

${ }^{56}$ C.A. Russell, Science and Theology, Leicester, Interversity Press, 1973, p. 626.

${ }^{57}$ H. Ross, op. cit., p. 22.

58 B. Lincoln, The Universe and Dr. Einstein, New York, William S. Associates, 1948, p. 106.

${ }^{59}$ Cf. G. Colin, "Knowledge and Culture: Towards an Epistemology of the Concrete" in Montefiore H., (ed.). Gospel and Contemporary Culture, New York, Mowbray, 1992, p. 93.

${ }^{60}$ P. Davies, op. cit. p. 3.

${ }^{61}$ F.W. Matson, The Broken Image, New York, Doubleday, 1966, chap. 2.

${ }^{62}$ A. Koestlerrin, Real Questions, Herts, Lion pub., 1982, p. 63.

${ }^{63}$ The report of a working party under the chairmanship of the Bishop of Salisbury,The Church And The Bomb, Toronto, Hodder And Stoughtgon, 1982, p. 13.

${ }^{64}$ M. Cooling, War and Pacifism, London, Scripture Union pub., 1988, p. 29. See also Gaudium et spes, Document of Second Vatican Council no.78.

${ }^{65}$ D. Alexander, op. cit., p. 103.

${ }^{66}$ F. Nietzsche, The Joyful Wisdom, London, FRANS. Common., 1910, p. 125.

${ }^{67}$ A. Camus, The Rebel, transl. B. Anthony, New York, Kroft pub., 1961, p. 280.

${ }^{68} \mathrm{Cf}$. Satre cited in D. Alexander, op. cit. P. 105.

${ }^{69}$ A. Camus, The Myth Of Sysplus and other essays, transl. O'Brien, J., New York, Vintage, 1985, p. 80.

${ }^{70}$ Cf. J. Watson, quoted in J. Hefley, Life in the Balance, Illinois, Victor Books, 1980, p. 66.

${ }^{71}$ Niremberge cited in D. Alexander, Beyond Science, Herts, Lion pub., 1972, p. 24.

${ }^{72}$ S. Karl, The Pillar Of Fire, New York, Harcourt Brace, 1951, pp. 127128.

${ }^{73}$ F. Schwarz, You Can Trust the Communists, California, Christian Anti Communism Crusade, 1960, p. 133.

74 J. Hefley, op. cit., p. 79.

75 P. Iroegbu, Enwisdomization and African Philosophy, Owerri, Int. University press, 1994, p. 66.

${ }^{76}$ D. Alexander, op. cit., p. 41. 
${ }^{77}$ D. Alexander, op. cit., p. 132.

${ }^{78}$ J. Maritain, The Person and The Common Good, transl. John F., Notre Damme, Indiana University press, 1966, p. 91.

${ }^{79}$ Hitchcock, The Decline And Fall Of Radical Catholicism, New York, Harder, 1971, p. 194.

${ }^{80}$ E. Bloch, Prinzip Hoffnung, Frankfurt, 1959, p. 319.

${ }^{81}$ Joseph Ratzinger is the incumbent Pope - Benedict XVI. He is a philosopher and a theologian. In his book, In the Beginning..., he elaborately dealt with the question on the relationship between science and religion.

82 J. B. Philips, God Our Contemporary, London, Cox and Wyman Pub., 1961, pp. 41-42.

${ }^{83}$ C.A. Coulson, Science and Christian Belief, Glasgow, Fontana, 1958, p. 103.

84 R.E. Peacock, A Brief History of Eternity, Eastbourne, Monarch pub.,1989, p. 21.

${ }^{85}$ G.T.W. Patrick, Introduction to Philosophy, Surjeet pub., 1978, p. 53.

${ }^{86}$ J.B. Philips, God our Contemporary, London, Cox and Wyman, 1961, p. 49.

${ }^{87}$ M. Midgley, op. cit., p. 53.

88 Cf. C. Waddington, The Scientific Attitude, Harmondsworth, Penguin, 1941, p. 170.

${ }^{89}$ B. Russel, A Freeman's Worship, London, Unwin, 1917, p. 54. 